\title{
Evaluasi Keakuratan Model Beneish M-Score Sebagai Alat Deteksi Kecurangan Laporan Keuangan (Kasus Perusahaan Pada Otoritas Jasa Keuangan di Indonesia)
}

\author{
Setyarini Santosa ${ }^{1}$, Josep Ginting ${ }^{2}$ \\ Accounting Study Program, President University

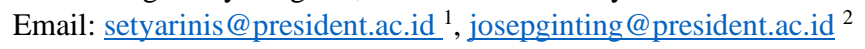

\section{ARTICLE INFO}

Keywords:

Fraud,

Beneish M-Score,

Logits,

$A Q I$,

TATA

\section{ABSTRACT}

This research has been conducted aiming to see in more detail whether the fraud detection model that has been used so far, the Beneish M-Score, is capable of being one of the tools to see financial report fraud occurring in the business world. This is interesting to study considering that many companies in the Financial Services Authority $(O J K)$ in Indonesia receive warnings and even fines for the delay in submitting financial reports to Capital Market Authority.

To carry out the analysis process as in the objectives in the first paragraph, the research team took a sample of 23 companies on the Indonesia Stock Exchange, where the companies were in the list of OJK. The 23 companies that were sanctioned by the OJK compared to 23 not sanctioned companies. In sample of companies that were sanctioned by the OJK, the number of non-manipulator companies according to the Beneish M-Score calculation was $62 \%$ and for companies included in the manipulator classification only 38\%. Whereas in the sample of companies not subject to sanctions from the OJK, the number of companies included in the non-manipulator category is actually smaller, 52\%, calculated using M-Score. This is the main basis for further research.

In this study, the analysis process is carried out by quantitative explanatory analysis using probit regression models (probit models), on financial statement data which are categorized into two, the financial ratio with original data from OJK (audited) and the financial ratio with data modification (advanced business analysis). The results show that Beneish M-Score Model could not be implemented effectively to detect the fraud in the companies under control by OJK because only 2 (two) variables influence the existence of fraudulent, are Asset Quality Index (AQI) and Total Accrual To Total Assets (TATA). Thus, it is appropriate and important for the Beneish M-Score modeling to be equipped with other models that are more able to explain.

\section{PENDAHULUAN}

Fraud adalah kondisi yang sering tidak disadari ataupun disadari dilakukan dengan tujuan baik atau tujuan tidak baik. Sangat sulit membedakan yang mana fraud dalam kriteria melanggar etika bisnis atau bahkan telah melanggar aturan perundang-undangan. Dalam paper ini dibahas dengan mengerucutkan kearah tindakan fraud dalam laporan keuangan. Beberapa kasus pelanggaran atau kecurangan yang telah ditangani oleh Otoritas Jasa Keuangan (OJK) antara lain adalah kasus PT Sari Husada Tbk, PT Great River Internasional Tbk, PT Agis, Tbk dan Katarina Utama Tbk PT Kimia Farma (Koroy, 2008), Bank Lippo (Iqbal \& Murtanto, 2016). Beberapa salah saji laporan keuangan memang belum tentu berkaitan dengan kecurangan, namun faktor-faktor risiko yang berkaitan dengan kecurangan manajemen terbukti ada pada kasus-kasus tersebut (Wahyuni \& Budiwitjaksono, 2017).

Ada tiga jenis fraud, yaitu korupsi, penyalahgunaan aktiva dan kecurangan laporan keuangan (Hall, 2016). Laporan 2016 Global Fraud Study yang dikeluarkan oleh ACFE Global menyatakan bahwa jenis fraud terbesar di dunia adalah penyalahgunaan aktiva, sedangkan kerugian terbesar disebabkan oleh kecurangan laporan keuangan (financial statement fraud) (ACFE, Report to the Nations on Occupational Fraud and Abuse: 2016 Global Fraud Study, 2017). Data ini berbeda dengan hasil survey Association of Certified Fraud Examiner (ACFE) Indonesia Chapter pada 2016 yang menyatakan bahwa jenis fraud 
terbanyak yang ditemukan adalah korupsi, yaitu sebesar $77 \%$ dari responden. Korupsi tersebut menelan kerugian terbesar di Indonesia dengan modus kerugian sebesar Rp 100 juta sampai dengan Rp 500 juta (ACFE, Survey Fraud Indonesia, 2017). Mengenai perbedaan hasil survey ini, ACFE Chapter Indonesia menyatakan adanya kemungkinan karena kejahatan atas fraud atau kecurangan laporan keuangan relatif belum banyak terungkap di Indonesia jika dibandingkan dengan kecurangan karena korupsi.

Otoritas Jasa Keuangan (OJK) adalah lembaga independen yang mengatur dan mengawasi pasar modal dan bank serta memberikan perlindungan pada konsumen industri jasa keuangan. Menurut website resmi OJK, lembaga ini melakukan beberapa inisiatif. Salah satu inisiatif terkait dengan pengendalian gratifikasi yang diharapkan dapat mengurangi tingginya masalah korupsi di Indonesia. Inisiatif lain yang dilakukan OJK adalah revitalisasi whistle blowing system serta inisiatif untuk anti fraud. Inisiatif anti fraud ini diarahkan untuk penyusunan strategi, pendidikan, pencegahan, deteksi serta penindakan kecurangan atau fraud, termasuk kecurangan laporan keuangan Sesuai dengan peran yang diembannya, maka OJK adalah lembaga yang memberikan sanksi pada perusahaan-perusahaan yang melanggar ketentuan. Pelanggaran ketentuan yang diberi sanksi oleh OJK diantaranya adalah keterlambatan penyampaian laporan keuangan, ditemukannya salah klasifikasi saji pada laporan keuangan, dan sebagainya. Adapun perusahaan yang diberi sanksi oleh OJK belum tentu selalu berarti perusahaan yang melakukan fraud atau kecurangan laporan keuangan

Literatur akademik menunjukkan bahwa dari laporan keuangan yang disajikan oleh perusahaan dapat dilakukan analisis untuk mendapatkan skor nilai apakah sebuah perusahaan dapat dikategorikan sebagai perusahaan manipulator yang memiliki kecenderungan untuk melakukan kecurangan laporan keuangan. Skor yang dikenal dengan sebutan Beneish M-Score ini dikembangkan oleh Profesor Messod Daniel Beneish. Model ini menggunakan 8 rasio keuangan untuk mendapatkan skor tertentu dalam rangka identifikasi kemungkinan terjadinya fraud pada perusahaan. Ke-8 rasio keuangan itu adalah Receivable Days Sales Index, Gross Margin Index, Asset Quality Index, Grow Sales Index, Depreciation Index, general and administration Sales Index, Leverage Index, Total Accrual to Total Assets Berdasarkan skor yang diperoleh maka sebuah perusahaan dapat dikategorikan dalam kelompok perusahaan manipulator dan non-manipulator. Beneish M-Score sendiri merupakan model probabilistic. (Beneish, 1999).

Beberapa penelitian telah dilakukan untuk melihat kemampuan Beneish M-Score untuk deteksi kecurangan laporan keuangan pada perusahaan-perusahaan yang ada di beberapa negara. Hasil yang diperoleh cukup beragam. Ada penelitian yang menyatakan bahwa Beneish M-Score efektif untuk mendeteksi fraud (Tarjo \& Herawati, 2015; Mahama, 2015; Omar, Koya, Sanusi, \& Shafie, 2014; Kartikasari \& Irianto, 2010), namun ada pula yang menyatakan bahwa skor ini tidak efektif untuk mendeteksi fraud (Mehta \& Bhavani, 2017; Bhavani \& Amponsah, 2017; Amoa-Gyarteng, 2014). Selain penelitian yang mencoba untuk melihat efektifitas Model Beneish M-Score untuk mendeteksi fraud, ada penelitian yang mencoba untuk melihat keberadaan pengaruh dan arah hubungan dan masing-masing rasio dari 8 rasio yang digunakan Beneish pada perusahaan-perusahaan publik yang terdaftar di Bursa Efek Indonesia (Darmawan, 2016; Hantono, 2018)

Penelitian tentang Beneish M-Score dengan konteks perusahaan-perusahaan yang ada di Indonesia, semestinya menggunakan data perusahaan-perusahaan yang terkena sanksi dari OJK selaku institusi yang memiliki otoritas untuk pengawasan fraud. Namun demikian data yang diperoleh dari OJK menyatakan bahwa perusahaan yang terkena sanksi dari OJK belum tentu merupakan perusahaan yang melakukan fraud. Penelitian Reskino dan Anshori (2016) telah menggunakan data perusahaan yang mendapat sanksi dari OJK, namun demikian penelitian ini tidak menggunakan Beneish M-Score untuk deteksi fraud (Reskino \& Anshori, 2016). Penelitian Kartikasari (2010) menggunakan sampel 2 perusahaan yang dikenai sanksi karena telah melakukan fraud oleh Bapepam. Hasil penelitian atas kedua kasus tersebut menyatakan bahwa sanksi yang diberikan ternyata sejalan dengan hasil perhitungan yang ditunjukkan oleh Beneish M-Score. Namun Kartikasari (2010) juga menyatakan perlunya penelitian lanjutan untuk memperluas sampel pada perusahaan yang belum benar-benar dinyatakan melakukan fraud untuk membuktikan sejauh mana model Beneish dapat digunakan untuk prediksi terjadinya kecurangan laporan keuangan pada perusahaan (Kartikasari \& Irianto, 2010).

Mengacu kepada penelitian-penelitian dan kondisi yang sebenarnya terjadi di dunia bisnis Indonesia maka masalah yang hendak dibahas dalam penelitian ini adalah pernyataan kelemahan Model Beneish MScore yang telah dikemukakan sebelumnya. Dalam penelitian ini akan dilakukan analisis terhadap sebagian rasio yang digunakan Beneish yang diduga mempengaruhi daya prediksi (ketepatan model) Beneish M-Score pada laporan keuangan perusahaan-perusahaan yang ada di Indonesia. 


\section{LITERATUR REVIEW}

\section{Kecurangan Laporan Keuangan}

Kecurangan atau fraud atau occupational fraud adalah penyalahgunaan sumber daya atau aset organisasi di pekerjaan yang dengan sengaja dilakukan dengan tujuan untuk memperkaya diri (ACFE, Fraud Resources, 2018).Adapun cara-cara yang digunakan untuk melakukan kecurangan tersebut dapat dilihat pada Fraud Tree: Occupational Fraud and Abuse Classification System yang dikembangkan oleh ACFE. Mengacu pada Fraud Tree tersebut, ada tiga macam skema kecurangan, yaitu korupsi, penyalahgunaan aset dan kecurangan laporan keuangan. Penelitian ini hanya meliputi kecurangan laporan keuangan. Skema kecurangan laporan keuangan berupa penyajian laba bersih yang terlalu tinggi atau terlalu rendah dengan cara memanipulasi data pada pos-pos laporan keuangan dan pengungkapannya (ACFE, Report to the Nations on Occupational Fraud and Abuse: 2016 Global Fraud Study, 2017).

Kecurangan laporan keuangan dapat diartikan sebagai adanya salah saji atau penghilangan dengan sengaja atas jumlah atau pengungkapan dalam laporan keuangan sehingga pemakai laporan keuangan jadi memiliki persepsi yang tidak benar terhadap laporan keuangan perusahaan (Kartikasari \& Irianto, 2010). Albrecht et al (2016) dalam (Kartikasari \& Irianto, 2010) menyatakan bahwa kecurangan laporan keuangan dapat berupa manipulasi, pemalsuan, perubahan catatan akuntansi atau dokumen pendukungnya yang menjadi sumber data bagi penyajian laporan keuangan. Selain itu kecurangan laporan keuangan juga dapat berupa salah menyajikan atau menghilangkan informasi atau transaksi yang memiliki pengaruh signifikan bagi laporan keuangan perusahaan ataupun terjadinya kesalahan penerapan prinsip akuntansi sehingga terjadi perbedaan dalam hal jumlah, klasifikasi, cara penyajian dan pengungkapan.

ACFE (2007) mengelompokkan kecurangan dalam bentuk earning overstatement dan earning understatement. Earning overstatement lebih sering dilakukan karena dengan skema earning overstatement yaitu pengakuan pendapatan atau laba lebih tinggi dari yang seharusnya akan menyebabkan peningkatan profitabilitas perusahaan. Wells (2005) dalam (Kartikasari \& Irianto, 2010) menyatakan beberapa praktek yang biasa dilakukan untuk menaikkan atau menurunkan asset atau laba perusahaan adalah: (Hariri, Wijayanti, \& Srilucky, 2017)

a. Kecurangan dalam penilaian asset seperti penetapan piutang dan persediaan yang lebih tinggi, manipulasi harga pembelian asset tetap dan kapitalisasi persediaan yang tidak sesuai

b. Mencatat transaksi penjualan fiktif yang berakibat pada overstatement aset dan pendapatan.

c. Melakukan understatement atas kewajiban dan beban seperti sengaja tidak mencatat atau menyembunyikan transaksi terkait beban dan kewajiban

d. Menyalahgunakan perbedaan waktu atau periode akuntansi misalnya dengan melakukan pengakuan pendapatan lebih cepat dari yang seharusnya atau menunda pengakuan beban.

e. Kecurangan dalam pengungkapan informasi pada laporan keuangan, seperti sengaja tidak memberikan informasi atau memberikan informasi yang menyesatkan kepada pemakai laporan keuangan.

\section{Penyebab Terjadinya Kecurangan Laporan Keuangan}

Fraud Triangle Theory yang dikembangkan pertama kalinya oleh Dr. Donald Cressey adalah teori yang digunakan untuk menjelaskan alasan terjadinya fraud atau kecurangan. Faktor penyebab terjadinya fraud ini digunakan sebagai framework yang diadopsi oleh SAS No 99 untuk deteksi laporan keuangan. Ada tiga faktor penyebab terjadinya fraud, yaitu tekanan, kesempatan dan rasionalisasi (Skousen, Smith, \& Wright, 2008; Abdullahi \& Mansor, 2015; Hall, 2016). Berdasarkan teori Cressey ini, Skousen (2008) melakukan penelitian empiris untuk mengembangkan proksi pengukuran untuk tekanan, kesempatan dan rasionalisasi dengan menggunakan data-data yang berasal dari laporan keuangan perusahaan (Skousen, Smith, \& Wright, 2008).

Tekanan dapat menjadi salah satu penyebab perusahaan melakukan kecurangan laporan keuangan. Tekanan ini dibedakan menjadi beberapa tipe, yaitu tekanan stabilitas keuangan, tekanan dari manajemen yang berlebihan untuk memenuhi persyaratan pihak eksternal, kondisi keuangan pribadi manajemen atau direktur perusahaan dan tekanan yang berlebihan pada manajemen untuk memenuhi target keuangan. (Skousen, Smith, \& Wright, 2008).

Penyebab terjadinya kecurangan laporan keuangan yang berikutnya adalah adanya kesempatan. Kesempatan untuk melakukan kecurangan akan semakin besar pada perusahaan yang berada pada sector industry tertentu, yang memiliki banyak jumlah transaksi yang tidak biasa, sangat kompleks dan lintas negara. Kesempatan melakukan kecurangan laporan keuangan juga meningkat pada perusahaan-perusahaan 
yang tidak memiliki struktur pengendalian internal yang cukup kuat serta aspek monitoring yang tidak berjalan dengan efektif (Skousen, Smith, \& Wright, 2008).

Rasionalisasi sebagai penyebab ketiga terjadinya fraud merupakan sikap mental yang dimiliki oleh top manajemen atau karyawan yang mengijinkan mereka untuk melakukan kecurangan karena justifikasi tertentu keterlibatan yang berlebihan pihak yang tidak seharusnya ketika hendak memiliki metode akuntansi tertentu, dan sebagainya

Namun demikian, meskipun ketiga faktor tersebut ada, tapi kemungkinan besar kecurangan tetap tidak terjadi jika (calon) pelaku tidak memiliki skill dan ability untuk merealisasikannya. Oleh karenanya Wolfe dan Hermanson mengembangkan Fraud Triangle Theory menjadi Fraud Diamond Theory, dengan menambahkan faktor ke-empat penyebab terjadinya fraud yaitu faktor capability atau kemampuan (Wolfe \& Hermanson, 2004). Perkembangan terakhir teori fraud ini adalah teori tentang The Crowe's Fraud Pentagon. Teori ini melengkapi ke-empat factor penyebab fraud dengan faktor ke 5 yaitu faktor arogansi. Jika fraud triangle merupakan kecurangan pada level manajemen tingkat menengah, maka fraud pentagon merupakan skema kecurangan pada level yang lebih tinggi yaitu CEO atau CFO (Aprilia A. , 2017)

\section{Beneish Model}

Beneish M-Score Model adalah model matematika yang digunakan untuk mendeteksi terjadinya fraud pada laporan keuangan (Mehta \& Bhavani, 2017; Tarjo \& Herawati, 2015). Cynthia (2005); Roxas (2011) dan Ugochukwuet (2013) dalam (Mehta \& Bhavani, 2017) menyatakan bahwa Beneish model adalah alat yang lebih baik daripada rasio keuangan untuk melakukan deteksi kecurangan atas laporan keuangan perusahaan. Beneish M-Score merupakan model probabilistic sehingga model ini tidak dapat 100\% memprediksi terjadinya kecurangan laporan keuangan yang akan terjadi.

Beneish menyatakan bahwa pada umumnya laporan keuangan perusahaan yang melakukan manipulasi laba akan menunjukkan peningkatan signifikan pada pendapatan dan penurunan signifikan pada akun beban antar periode akuntansi (Beneish, 1999; Kartikasari \& Irianto, 2010). Beneish menggunakan delapan rasio terkait perubahan asset dan pertumbuhan penjualan untuk mengukur Beniesh M-Score. Apabila skor yang diperoleh diatas -2,22, maka perusahaan dikatakan memiliki kecenderungan untuk manipulasi atau manipulator. Sedangkan jika Beneish M-Score perusahaan lebih kecil dari -2,22, maka dapat dikatakan perusahan tersebut tidak melakukan manipulasi atau berada dalam kelompok perusahaan non-manipulator. Adapun delapan rasio yang digunakan Beneish adalah sebagai berikut: (Beneish, 1999; Kartikasari \& Irianto, 2010)

a. Days' sales in receivables index atau DSRI adalah indeks jumlah hari atas penjualan kredit pada tahun pertama terjadinya dugaan manipulasi laba dibandingkan dengan tahun sebelumnya. Perhitungan DSRI yang lebih dari 1 (satu) menunjukkan semakin tinggi kemungkinan terjadinya overstatement pada laba atau pendapatan. Jika kenaikan jumlah harinya tinggi dapat diartikan barangkali perusahaan membuat perubahan kebijakan kredit untuk mendorong percepatan penjualan. Sedangkan peningkatan piutang yang tidak sebanding dengan penjualan dapat juga diartikan terjadinya penggelembungan pendapatan.

b. Gross Margin Index atau Indeks Laba Kotor atau GMI yang merupakan ukuran tingkat profitabilitas perusahaan. Indeks ini merupakan perbandingan perubahan laba kotor pada satu tahun dengan tahun sebelumnya. Indeks Laba Kotor ini memberikan gambaran tentang prospek perusahaan dimasa yang akan datang. GMI yang lebih dari angka 1 (satu) merupakan sinyal terjadinya overstatement pada laba.

c. Assets Quality Index atau Indeks Kualitas Aset atau AQI merupakan perbandingan asset tidak lancar selain asset tetap dengan total asset pada tahun sekarang dengan tahun sebelumnya. Indeks ini menunjukkan ukuran kualitas asset tidak lancar yang dapat memberikan manfaat dimasa yang akan datang. Jika indeks ini lebih besar dari 1 (satu), maka terjadi penurunan kualitas asset, artinya terjadi peningkatan jumlah asset tidak lancar yang dapat memberikan manfaat masa depan dan ini berarti juga terjadinya peningkatan jumlah beban yang ditangguhkan. Ini merupakan indikasi terjadinya overstatement pada laba.

d. Sales Growth Index atau Indeks Pertumbuhan Penjualan atau SGI merupakan perbandingan penjualan pada dua periode. Jika SGI lebih dari 1 (satu) maka berarti terjadi peningkatan penjualan yang dapat diartikan adanya kemungkinan terjadi overstatement pada laba.

e. Depreciation Index atau Indeks Beban Penyusutan atau DEPI yang merupakan perbandingan beban depresiasi terhadap asset tetap sebelum depresiasi antar periode. Jika indeks ini melebihi 1 (satu) maka terdapat sinyal overstatement pada laba. Indeks lebih dari 1 berarti terjadi penurunan beban penyusutan 
asset tetap, sedangkan penurunan rasio ini menunjukkan terjadinya peningkatan beban penyusutan asset tetap.

f. Sales, General and Administrative Expenses Index atau Indeks Beban Penjualan, Umum dan Administrasi atau SGAI merupakan indeks yang mengukur perbandingan antara beban penjualan, administrasi dan umum terhadap penjualan antaa dua periode. SGAI lebih kecil dari 1 berarti terjadi penurunan beban opersioanal perusahaan atau kenaikan penjualan. Hal ini mengindikasikan terjadinya overstatement pada laba.

g. Leverage Index atau indeks hutang atau LVGI merupakan rasio perbandingan antara jumlah hutang terhadap total asset pada tahun ini dengan tahun sebelumnya. Hal ini menggambarkan tingkat hutang yang dimiliki perusahaan terhadap total asset dari tahun ke tahun. Jika LVGI lebih besar dari 1 maka terjadi peningkatan komposisi hutang atas asset yang berpotensi terhadap kemungkinan overstatement pada laba karena perusahaan memiliki kewajiban untuk memenuhi kewajibannya.

h. Total accrual to total asset atau Indeks Total Akrual terhadap Total Aset atau TATA. Total akrual merupakan komponen pembentuk jumlah laba akrual. Tingginya jumlah total akrual menggambarkan porsi kas pada laba yang dihasilkan rendah. Nilai TATA yang tinggi memberikan sinyal terjadinya overstatement terhadap laba.

Adapun rumus untuk mendapatkan Beneish M-Score adalah :

$\mathrm{M}=-4.84+0.92 * \mathrm{DSRI}+0.528 * \mathrm{GMI}+0.404 * \mathrm{AQI}+0.892 * \mathrm{SGI}+0.115 * \mathrm{DEPI}-$

$0.172 * \mathrm{SGAI}+4.679 * \mathrm{TATA}-0.327 * \mathrm{LVGI}$

\section{Hipotesis Penelitian}

Dalam analisa pendahuluan 23 perusahaan yang terkena sanksi dari OJK dan 23 perusahaan yang tidak terkena sanksi dari OJK, ternyata Beneish M-Score tidak dapat sepenuhnya terkonfirmasi untuk dapat digunakan sebagai model deteksi kecurangan laporan keuangan. Hal ini menunjukkan perlunya modifikasi atau definisi ulang atas rasio atau indeks pembentuk Beneish M-Score. Sebagai contoh, current asset yang dihitung dalam model Beneish adalah seluruh current asset. Jika AQI adalah indeks kualitas current asset yang dapat memberi manfaat dimasa yang akan datang, maka semestinya hanya aktiva produktif yang akan diperhitungkan dalam perhitungan indeks ini. Demikian juga dengan hutang. Indeks hutang merupakan rasio perbandingan jumlah hutang terhadap total aktiva. Investor dan kreditor akan lebih memperhatikan hutang yang menggunakan bunga karena tipe hutang ini lebih memberikan manfaat bagi mereka selaku pemberi pinjaman sehingga perusahaan akan memiliki peluang lebih besar untuk melakukan kecurangan pada akun ini, jika dibanding hutang tanpa bunga yang memiliki tingkat resiko lebih rendah bagi perusahaan.

Untuk itu hipotesa yang hendak dibuktikan dalam penelitian ini adalah:

H1 : Model Beneish M-Score dengan rasio keuangan data OJK efektif diterapkan di Indonesia

H2 : Model Beneish M-Score dengan modifikasi rasio keuangan data OJK efektif diterapkan di Indonesia

\section{Data}

Sampel penelitian ini menggunakan data sekunder yang diambil dari OJK dan Bursa Efek Indonesia. Sample dari OJK berupa perusahaan yang mendapat sanksi dari OJK. Sanksi tersebut disebabkan oleh perusahaan yang terlambat menyampaikan laporan keuangannya dan sanksi lain seperti ditemukannya salah saji pada laporan keuangan. Perusahaan yang diambil sebagai sampel adalah perusahaan yang terkena sanksi OJK pada periode 2012 -2017. Adapun data yang diperoleh adalah seperti Tabel 3.1

\section{Tabel 3.1}

Data Jumlah Kasus yang Diberi Sanksi oleh OJK

\begin{tabular}{|l|c|c|c|c|c|c|}
\hline Jenis Sanksi & 2012 & 2013 & 2014 & 2015 & 2016 & total \\
\hline Terlambat menyampaikan LK & 95 & 115 & 80 & 70 & 97 & 457 \\
\hline Sanksi lain & 16 & 8 & 6 & 5 & 3 & 38 \\
\hline & 111 & 123 & 86 & 75 & 100 & $\mathbf{4 9 5}$ \\
\hline
\end{tabular}

Dari data OJK tersebut dilakukan pengambilan sampel dengan kriteria sebagai berikut:

a. Perusahaan yang terdaftar di BEI yang mendapatkan sanksi dari OJK minimum 2 kali melakukan keterlambatan penyampaian laporan keuangan pada periode 2012 -2016.

b. Bank, perusahaan asuransi, perusahaan investasi dan jasa serta institusi keuangan lainnya dikeluarkan dari sampel 
c. Laporan yang memiliki laporan keuangan yang dibutuhkan untuk menghitung rasio dan indeks yang dibutuhkan dalam penelitian ini.

d. Laporan keuangan yang diambil sebagai sampel adalah laporan keuangan saat terjadinya sanksi dan laporan keuangan 2 tahun sebelum diperolehnya sanksi tersebut.

Setelah menerapkan kriteria sampel diatas, maka jumlah sampel yang digunakan untuk penelitian ini adalah 212 laporan keuangan perusahaan untuk uji Beneish M-Score dengan formula awal dan 200 laporan keuangan perusahaan untuk uji Beneish M-Score yang menggunakan definisi operasional yang baru.

\section{METODE ANALISIS DATA}

Data diolah dengan menggunakan regresi linier berganda dengan bantuan software E-Views 10.

Akan dibuat dua persamaan, yaitu:

1. $\mathrm{Y} 1=\mathrm{a}+\beta 1 \mathrm{DSRI}+\beta 2 \mathrm{GMI}+\beta 3 \mathrm{AQI}+\beta 4 \mathrm{SGI}+\beta 5 \mathrm{DEPI}+\beta 6 \mathrm{SGAI}+\beta 7 \mathrm{TATA}+\beta 8$

LVGI+ e

2. $\mathrm{Y} 2=\mathrm{a}+\beta 1 \mathrm{DSRI}+\beta 2 \mathrm{GMI}+\beta 3 \mathrm{AQI}$ (modified) $+\beta 4 \mathrm{SGI}+\beta 5 \mathrm{DEPI}$ (modified) $+\beta 6 \mathrm{SGAI}$

$+\beta 7$ TATA (modified) $+\beta 8$ LVGI (modified) $+\mathrm{e}$

Dimana Y1 dan Y2 adalah Beneish M-Score yang mencerminkan perusahaan manipulator dan nonmanipulator.

Mengingat penelitian ini menggunakan model probit, maka langkah awal akan dilakukan uji asumsi klasik, kemudian akan dilihat goodness of fit dari model dan setelah itu akan dilakukan uji F dan uji t untuk menjawab pertanyaan penelitian.

Rasio atau indeks pembentuk Beneish M-Score diperoleh dari komponen aktiva, hutang dan komponen pembentuk laba operasional. Beberapa akun yang dipergunakan dalam perhitungan Beneish MScore adalah kas, piutang, aktiva lancar, aktiva tetap, total aktiva, hutang jangka panjang yang jatuh tempo, hutang lancar, hutang pajak, penjualan, harga pokok penjualan, depresiasi dan amortisasi, beban penjualan, umum dan administratif.

Modifikasi rumus indeks pembentuk M-Score dilakukan berdasarkan pertimbangan:

a. Aktiva memiliki tiga karakteristik yaitu adanya manfaat ekonomi dimasa yang akan datang, kemampuan perusahaan untuk melakukan kontrol atas aktiva yang dimilikinya serta karakteristik bahwa aktiva tersebut dihasilkan oleh transaksi yang telah dilakukan sebelumnya. Karakteristik aktiva yang masih diperdebatkan sampai sekarang adalah daya tukar atau exchangability yaitu aktiva dapat dilepaskan dari perusahaan dan dapat dengan mudah diperjualbelikan di pasar (Godfrey, Hodgson, Tarca, Hamilton, \& Holmes, 2010). Pertimbangan untuk mengubah definisi operasional current asset yang digunakan dalam perhitungan Beneish M-Score adalah adanya tantangan dalam pelaporan asset, yaitu adanya ketidakjelasan atau ketidakpastian kepemilikan aktiva, ketidakpastian manfaat masa depan dan perubahan pada nilai aktiva itu sendiri (Palepu, Healy, \& Bernard, 2003). Mengingat pentingnya karakteristik manfaat dimasa yang akan datang yang harus dimiliki oleh sebuah asset serta pertimbangan pengukuran dimasa yang akan datang, maka produktifitas asset akan menjadi penting dalam hal ini. Exchangeability juga berarti timbulnya manfaat dimasa yang akan datang. Untuk itulah maka seluruh akun atau rasio yang menggunakan aktiva lancar atau current asset dalam 8 rasio atau indeks pembentuk Beneish M-Score tampaknya akan lebih tepat jika menggunakan aktiva lancar produktif. Dengan menggunakan persyaratan aktiva yang memenuhi karakteristik exchangeablity dan produktif, maka Prepaid Expenses, Prepaid Tax, Advance Payment, Deferred Tax Assets, Work-inprocess inventory and Construction-in-progress of PPE akan dikeluarkan dari perhitungan tersebut.

b. Investor membayar beban bunga untuk aktiva, tentunya mereka berharap sumber daya yang mereka investasikan dapat dibelanjakan dengan bijak oleh manajemen dan akhirnya dapat menghasilkan laba bagi perusahaan. Pelaporan aktiva masih terkendala dengan adanya ketidakjelasan atau ketidakpastian kepemilikan sumber daya, kesulitan untuk mengukur atau ketidakpastian penerimaan manfaat dimasa yang akan datang serta perubahan nilai sumber daya yang ada di perusahaan. 


\section{HASIL DAN PEMBAHASAN}

1. Persamaan dengan menggunakan rasio keuangan data laporan keuangan yang belum dimodifikasi :

a. Goodness of Fit Test

Chi-Square Tests

\begin{tabular}{|c|c|c|c|}
\hline & Chi-Square & $\frac{d f^{a}}{}$ & Sig. \\
\hline PROBIT Pearson Goodness-of-Fit Test & 389.956 & 175 & .000 \\
\hline
\end{tabular}

a. Statistics based on individual cases differ from statistics based on aggregated cases.

Apabila dilihat dari angka Goodness of Fit Test maka Chi Square sebesar 389,956 menunjukkan angka fit dengan data yang dianalisa. Dengan demikian estimasi yang digunakan dengan menggunakan probit dapat diteruskan.

b. Estimasi Probit Regression

\section{Parameter Estimates}

\begin{tabular}{|c|c|c|c|c|c|c|c|}
\hline & \multirow[b]{2}{*}{ Parameter } & \multirow[b]{2}{*}{ Estimate } & \multirow[b]{2}{*}{ Std. Error } & \multirow[b]{2}{*}{ Z } & \multirow[b]{2}{*}{ Sig. } & \multicolumn{2}{|c|}{ 95\% Confidence Interval } \\
\hline & & & & & & Lower Bound & Upper Bound \\
\hline PROBIT $^{\mathrm{a}}$ & DSRI & .055 & .041 & 1.353 & .176 & -.025 & .135 \\
\hline & GMI & .035 & .042 & .827 & .408 & -.048 & .118 \\
\hline & AQI & .042 & .024 & 1.714 & .086 & -.006 & .090 \\
\hline & SGI & .074 & .058 & 1.280 & .201 & -.039 & .188 \\
\hline & DEPI & .035 & .064 & .551 & .582 & -.091 & .161 \\
\hline & SGAI & .011 & .063 & .181 & .856 & -.111 & .134 \\
\hline & LVGI & .034 & .099 & .341 & .733 & -.160 & .228 \\
\hline & TATA & .624 & .367 & 1.700 & .089 & -.095 & 1.343 \\
\hline & Intercept & -2.981 & .392 & -7.610 & .000 & -3.373 & -2.590 \\
\hline
\end{tabular}

a. PROBIT model: PROBIT(p) $=$ Intercept + BX

Menggunakan Probit Regression sehubungan dengan data Beneish yang merupakan dummy antara adanya fraud dan tidak ada fraud, pada penelitian dihasilkan persamaan sebagai berikut :

Fraud Estimasi $=-2,981+0.624 \mathrm{TATA}+0,034 \mathrm{LVGI}+0,011 \mathrm{SGAI}+0,35 \mathrm{DEPI}+0,074 \mathrm{SGI}$

$$
+0,042 \mathrm{AQI}+0,035 \mathrm{GMI}+0,55 \mathrm{DSRI}
$$

c. Data Deskriptif

Descriptive Statistics

\begin{tabular}{|l|r|r|r|}
\hline & \multicolumn{1}{|c|}{ Mean } & Std. Deviation & $\mathrm{N}$ \\
\hline MScore & .3889 & .48901 & 162 \\
DSRI & 1.1359 & .87674 & 162 \\
GMI & .8398 & 1.18773 & 162 \\
AQI & 1.3332 & 1.77737 & 162 \\
SGI & 1.1106 & .64587 & 162 \\
DEPI & 1.1488 & .91881 & 162 \\
SGAI & 1.2595 & 1.11938 & 162 \\
LVGI & 1.1812 & .90081 & 162 \\
TATA & -.0442 & .12704 & 162 \\
Obs & 81.5000 & 46.90949 & 162 \\
\hline
\end{tabular}

2. Persamaan dengan menggunakan rasio keuangan data laporan keuangan yang telah dimodifikasi :

a. Goodness of Fit Test 


\section{Chi-Square Tests}

\begin{tabular}{|ll|r|r|r|}
\hline & Chi-Square & \multicolumn{1}{c|}{$\mathrm{df}^{\mathrm{a}}$} & \multicolumn{1}{c|}{ Sig. } \\
\hline PROBIT & $\begin{array}{l}\text { Pearson Goodness-of-Fit } \\
\text { Test }\end{array}$ & 247.710 & 152 & .000 \\
\hline
\end{tabular}

a. Statistics based on individual cases differ from statistics based on aggregated cases.

Regresi menggunakan model probit mengingat adanya faktor dummy yang merupakan angka indikasi adanya fraud pada laporan keuangan pada penelitian adalah baik menginga angka Chi Square 247,710 menunjukkan persamaan fit dengan data yang digunakan.

b. Estimasi Probit Regression

\begin{tabular}{|l|r|r|r|r|r|r|r|}
\hline & & & & & \multicolumn{2}{|c|}{ 95\% Confidence Interval } \\
\cline { 6 - 8 } & & & & & \multicolumn{1}{c|}{ Parameter Estimates } \\
\hline PROBIT $^{\mathrm{a}}{ }^{2}$ & DSRI & .060 & .048 & 1.256 & .209 & -.034 & .155 \\
& GMI & .055 & .074 & .750 & .453 & -.089 & .200 \\
& AQI & .109 & .031 & 3.507 & .000 & .048 & .170 \\
SGI & .137 & .107 & 1.277 & .202 & -.073 & .347 \\
DEPI & .033 & .072 & .463 & .643 & -.108 & .174 \\
SGAI & .021 & .065 & .332 & .740 & -.105 & .148 \\
LVGI & -.027 & .059 & -.460 & .645 & -.142 & .088 \\
TATA & .994 & .521 & 1.908 & .056 & -.027 & 2.015 \\
Intercept & -3.064 & .286 & -10.711 & .000 & -3.351 & -2.778 \\
\hline
\end{tabular}

a. PROBIT model: $\operatorname{PROBIT}(\mathrm{p})=$ Intercept $+\mathrm{BX}$

Pada penelitian ini dari data yang telah dimodifikasi dalam beberapa akun di laporan keuangan maka persamaan yang dihasilkan dari logit model adalah sebagai berikut :

Fraud Estimasi = -3,064 + 0,994TATA -0,027LVGI + 0,021SGAI + 0,33DEPI + 0,137SGI +

$$
0,109 \mathrm{AQI}+0,055 \mathrm{GMI}+0,060 \mathrm{DSRI}
$$

c. Data Deskriptif

\section{Descriptive Statistics}

\begin{tabular}{|l|r|r|r|}
\hline & \multicolumn{1}{|c|}{ Mean } & Std. Deviation & \multicolumn{1}{c|}{$\mathrm{N}$} \\
\hline MScore & .3889 & .48901 & 162 \\
DSRI & 1.1359 & .87674 & 162 \\
GMI & .8398 & 1.18773 & 162 \\
AQI & 1.3332 & 1.77737 & 162 \\
SGI & 1.1106 & .64587 & 162 \\
DEPI & 1.1488 & .91881 & 162 \\
SGAI & 1.2595 & 1.11938 & 162 \\
LVGI & 1.1812 & .90081 & 162 \\
TATA & -.0442 & .12704 & 162 \\
Obs & 81.5000 & 46.90949 & 162 \\
\hline
\end{tabular}

Dari pengolahan data yang dilakukan terhadap laporan keuangan yang belum dianalisis dan dimodifikasi sehubungan dengan interprestasi adanya dugaan penyebab fraud pada akun-akun tertentu di laporan keuangan dihasilkan bahwa hanya AQI dengan angka sig 0,086 dan TATA dengan angka sig 0,89 yang menunjukkan signifikan mempengaruhi adanya fraud pada laporan keuangan. Sementara pada rasio keuangan yang datanya telah dimodifikasi dengan meniadakan akun-akun tertentu dalam laporan keuangan yang diduga menjadi penyebab adanya fraud pada laporan keuangan maka hanya AQI dengan angka sig 0,000 dan TATA dengan angka sig 0,056 yang mempengaruhi secara signifikan akan adanya estimasi terjadi fraud pada laporan keuangan. 


\section{KESIMPULAN}

Dari analisis yang dilakukan dengan menggunakan Probit Model terhadap data laporan keuangan yang asli dan yang telah dimodifikasi berdasarkan dugaan sumber fraud maka dapat dikesimpulkan bahwa Model Beneish M-Score dengan menggunakan rasio keuangan dengan data sebelum dan sesudah modifikasi tidak efektif digunakan mengingat dari 8 (delapan) rasio yang digunakan hanya AQI dan TATA yang signifikan mempengaruhi angka dummy Beneish M-Score. Dengan demikian dunia akuntansi membutuhkan penelitian berikutnya berupa model deteksi kecurangan laporan keuangan.

\section{DAFTAR PUSTAKA}

Abdullahi, R., \& Mansor, N. (2015, October). Fraud Triangle Theory and Fraud Diamond Theory: Understanding the Convergent and Divergent for Future Research. International Journal of Academic Research in Accounting, Finance and Management Sciences, 5(4), 38-45. doi:10.6007/IJARAFMS/v5-3/1823

ACFE. (2017). Report to the Nations on Occupational Fraud and Abuse: 2016 Global Fraud Study. AustinTexas: Association of Certified Fraud Examiner Global.

ACFE. (2017). Survey Fraud Indonesia. Jakarta: ACFE Indonesia Chapter.

ACFE. (2018). Fraud Resources. (@ 2018 Association of Certified Fraud Examiners, Inc. All rights reserved) Retrieved Mei 31, 2018, from Report to the Nation: http://www.acfe.com/fraud-101.aspx

Amoa-Gyarteng, K. (2014). Analyzing a Listed Firm in Ghana for Early Warning Signs of Bankruptcy and Financial Statement Fraud: An Empirical Investigation of AngloGold Ashanti. European Journal of Business and Management, 6(5).

Aprilia, A. (2017). Analisis Pengaruh Fraud Pentagon Terhadap Kecurangan Laporan Keuangan Menggunakan Beneish Model Pada Perusahaan Yang Menerapkan Asean Corporate Governance Scorecard. Jurnal Akuntansi Riset, 9(1), 101 -132.

Aprilia, Cecilia, O., \& Sergius, R. P. (2015). The Effectiveness of Fraud Triangle on Detecting Fraudulent Financial Statement: Using Beneish Model and the Case of Special Companies. Jurnal Riset Akuntansi dan Keuangan, 3(3), 786 - 800.

Aris, N. A., Othman, R., Arif, S. M., Malek, M. A., \& Omar, N. (2013). Fraud Detection: Benford's Law vs Beneish Model. IEEE Symposium on Humanities, Science and Engineering Research. Retrieved from https://www.researchgate.net/publication/259783068

Beneish, M. D. (1999, September). The Detection of Earning Manipulation. Financial Analysts Journal, 55(5), 24-36. doi:DOI: 10.2469/faj.v55.n5.2296

Bhavani, G., \& Amponsah, C. T. (2017). M-Score and Z-Score for Detection of Accounting Fraud. Accountancy Business and the Public Interest 2017.

doi:https://www.researchgate.net/publication/318489930

Dalniala, H., Kamaluddina, A., \& Sanusia, Z. M. (2015). Accountability in Financial Reporting: Detecting Fraudulent Firms. Procedia - Social and Behavioral Sciences(145), 61 - 69.

Darmawan, A. Z. (2016). Analisis Beneish Ratio Index untuk Mendeteksi Kecurangan Laporan Keuangan Perusahaan Manufaktur yang Listing di Bursa Efek Indonesia Tahun 2013-2014. Retrieved from https://eprints.uny.ac.id/33429/

Godfrey, J., Hodgson, A., Tarca, A., Hamilton, J., \& Holmes, S. (2010). Accounting Theory (7th ed.). John Wiley \& Sons, Inc.

Hall, J. A. (2016). Accounting Information Systems (9 th ed.). New York: Cangage Learning. 
Hantono. (2018). Deteksi Financial Statement Fraud Melalui Model Beneish pada Perusahaan BUMN. Jurnal Manajemen Bisnis dan Inovasi, 5(3), 135 - 150.

Hariri, Wijayanti, A., \& Srilucky. (2017). Predicting Financial Statements Corporate Fraud: Beneish MScore Model. Jurnal Ilmiah Bidang Akuntansi dan Management, 14(2). doi:http://dx.doi.org/10.31106/jema.v14i02.506

Iqbal, M., \& Murtanto. (2016). Analisa Pengaruh Faktor Faktor Fraud Triangle terhadap Kecurangan Laporan Keuangan pada Perusahaan Properti dan Real Estate. Seminar Nasional Cendekiawan.

Kartikasari, R. N., \& Irianto, G. (2010, Agustus). Penerapan Model Beneish (1999) dan Model Altman (2000) dalam Pendeteksian Kecurangan Laporan Keuangan. Jurnal Akuntansi Multiparadigma, 1(2), 323 - 340. doi:http://dx.doi.org/10.18202/jamal.2010.08.7096

Kassem, R., \& Higson, A. (2012). The New Fraud Triangle Model. Journal of Emerging Trends in Economics and Management Science, 3(3), 191 - 195.

Koroy, T. R. (2008, Mei). Pendeteksian Kecurangan (Fraud) Laporan Keuangan oleh Auditor Eksternal. Jurnal Akuntansi dan Keuangan, 10(1), 22=33.

Mahama, M. (2015, January). Detecting Corporate Fraud and Financial Distress Using the Altman and Beneish Model: The Case of Enron Corp. International Journal of Economics, Commerce and Management, III(1). Retrieved from http://ijecm.co.uk/

Mehta, A., \& Bhavani, G. (2017). Application of Forensic Tools to Detect Fraud - The Case of Toshiba.

Omar, N., Koya, R. K., Sanusi, M. Z., \& Shafie, A. N. (2014, April). Financial Statement Fraud: A Case Examination Using Beneish Model and Ratio Analysis. International Journal of Trade, Economics and Finance, 5(2). Retrieved from https://www.researchgate.net/publication/271294108

Palepu, K., Healy, P., \& Bernard, V. (2003). Business Analysis and Valuation: Using Financial Statements, Text \& Cases. (3rd, Ed.) Thomson/South-Western Publisher.

Prehantika, F. K. (2016). Deteksi Financial Fraud dengan Model Beneish M-Score. Jurnal Akuntansi UNESA, 5(1).

Reskino, \& Anshori, M. F. (2016, Agustus). Model Pendeteksian Kecurangan Laporan Keuangan dengan Analisis Fraud Triangle. Jurnal Akuntansi Multiparadigma, 7(2), 256 - 269.

doi:http://dx.doi.org/10.18202/jamal.2016.08.7020

Skousen, C. J., Smith, K. R., \& Wright, C. J. (2008). Detecting and Predicting FInancial Statement Fraud: The Effectiveness of the Fraud Triangle and SAS No. 99. http://ssrn.com/abstract=1295494. doi:https://dx.doi.org/10.2139/ssrn.1295494

Tarjo, \& Herawati, N. (2015). Application of Beneish M-Score Models and Data Mining to Detect Financial Fraud. Procedia - Social and Behavioral Sciences, 211, 924 - 930.

Wahyuni, \& Budiwitjaksono, G. (2017, Januari). Fraud Triangle sebagai Pendeteksi Kecurangan. Jurnal Akuntansi, XXI(01), 47 - 61.

Wolfe, D. T., \& Hermanson, D. R. (2004). The Fraud Diamond: Considering the Four Elements of Fraud. The CPA Journal, 38 - 42. 